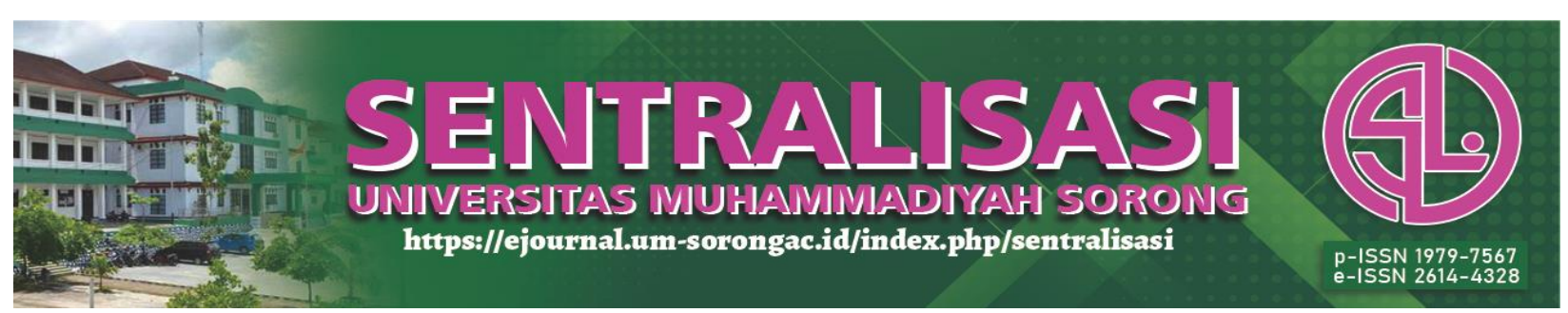

\title{
Effect of Free Cash Flow, Enterprise Risk Management Disclosure and Sustainability Report on Company Value With Good Corporate Governance as Moderating Variable
}

\author{
Nur Aeni Waly ${ }^{*}$, Noer Sasongko ${ }^{2}$, Fatchan Achyani ${ }^{3}$ \\ 1,2, ${ }^{3}$ Faculty of Economics, University of Muhammadiyah Surakarta, Indonesia \\ E-mail : *nur.aeniwaly97@gmail.com \\ *corresponding author
}

direvisi: 18/06/2021 dipublikasikan: 30/06/2021

\begin{abstract}
Abstrak. Penelitian ini bertujuan untuk menganalisis pengaruh free cash flow, enterprise risk management disclosure, sustainability report terhadap nilai perusahan dengan good corporate governance sebagai variabel moderating yang terdaftar pada perusahaan jakarta islamic indeks selama periode 2015 2019.Sampel yang digunakan sebanyak 57 perusahaan di (JII) periode 2015 - 2019. Metode analisis data yang digunakan yaitu regresi berganda dengan bantuan Spss 26 untuk menganalisis pengaruh moderating.Hasil analisis ini menunjukkan bahwa free cash flow tidak berpengaruh terhadap nilai perusahaan, enterprise risk management disclosure berpengaruh terhadap nilai perusahaan, sustainability report tidak berpengaruh terhadap nilai perusahaan, dan good corporate governance tidak memoderasi hubugan antara free cashflow terhadap nilai perusahaan, good corporate governance memoderasi hubugan antara enterprise risk management disclosure terhadap nilai perusahaan, dan good corporate governance tidak memoderasi hubugan antara sustainability report terhadap nilai perusahaan.
\end{abstract}

Kata kunci: Free Cash Flow, Enterprise Risk Management Disclosure, Sustainability Report, Nilai Perusahaan, dan Good Corporate Governance.

\begin{abstract}
Abstrak. This study aims to analyze the effect of free cash flow, enterprise risk management disclosure, and sustainability report on the value of companies with good corporate governance as a moderating variable listed on the Jakarta Islamic Index companies during the 2015-2019 periods. The samples used were 57 companies in (JII) period 2015 - 2019. The data analysis method used is multiple regressions with the help of Spss 26 to analyze the moderating effect. The results of this analysis show that free cash flow has no effect on firm value, enterprise risk management disclosure does not affect firm value, sustainability report does not has an effect on firm value, and good corporate governance does not moderate the relationship between free cash flow and firm value, good corporate governance moderates the relationship between enterprise risk management disclosure on firm value, and good corporate governance does not affect firm value. moderation of the relationship between the sustainability report and the value of the company.
\end{abstract}

Keywords: Free Cash Flow, Enterprise Risk Management Disclosure, Sustainability Report, Company Value, and Good Corporate Governance.

\section{Introduction}

Business competition is growing, encouraging companies to continue to improve their company's performance in order to survive and compete with other companies. In addition, the company has a main goal, namely increasing the value of the company. Then, the company has other goals, namely for the short term and for the long term. Where, the short term itself aims to maximize profit, while for the long term itself the main goal is to become a company's priority in increasing company value.

This study refers to research conducted by Fatchan \& Trisnawati (2016). Free cash flow is the most accrual indicator and is often used by investors to assess company performance. By 


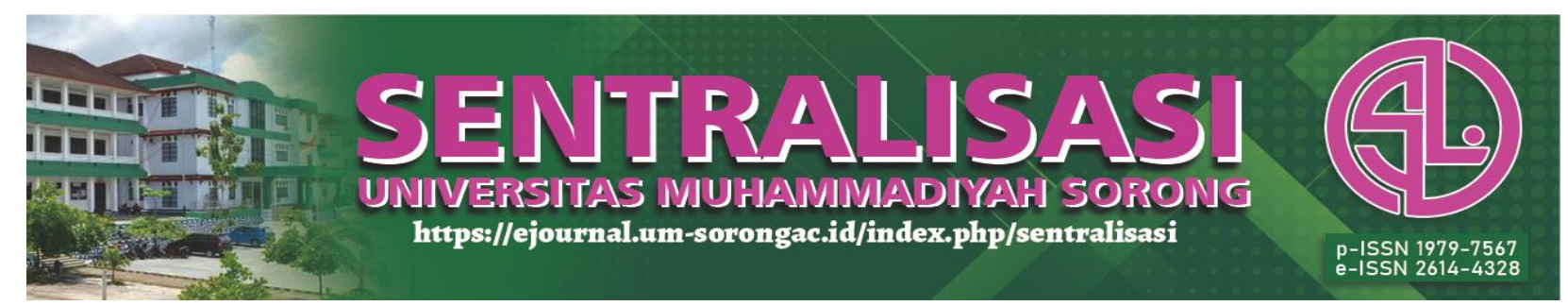

looking at Free cash flow, investors can know the company's growth from year to year. According to Richardson (2006) the cash flow owned by the company is related to the value of the company. The company's positive cash flow will reflect the company's good level of operational performance. Improved good performance will have an impact on increasing the value of a company.

The company will be considered good if it is able to disclose information widely because it is considered to have been able to apply the principle of transparency (Devi, et al., 2017). ERM is a systematic and continuous process designed and carried out by management to provide adequate assurance that all risks that have the potential to have a negative impact have been managed in such a way according to the level of risk that the company is willing to take. Luthfiyanti \& Dahlia (2020).

According to Kurniawan, et al., (2018) Sustainability Report is a form of corporate responsibility that must be considered in economic, social, and environmental aspects and is considered important because it is able to show transparency to stakeholders who can increase public trust in the company, and can also increase company value. .

Good Corporate governance is indispensable in encouraging the creation of an efficient, transparent and consistent market with laws and regulations. Regulations in GCG are needed to support three interrelated pillars, such as the state and its apparatus as regulators and the business world.

\section{Research Methods}

Based on the type of data, this research is quantitative. Meanwhile, the population is companies registered in the Jakarta Islamic Index (JII) for the period 2017 - 2019. This technique uses the Purposive Sampling method. The data analysis techniques used in this study are:

\section{The value of the company}

Firm value is measured using the Price to Book Value (PBV) formation.

PBV $=\frac{\text { Price Per Share }}{\text { Book Value Per Share }}$

\section{Free Cash Flow}

\section{FCF = NOPAT - investasi bersih pada modal operasi}

\section{Enterprise Risk Management Disclosure}

$$
\text { ERMD }=\frac{\text { Total ERM Item Score Disclosed }}{\text { Total ERM Items That Should Have Been Disclosed }} .
$$

\section{Sustainability Report}

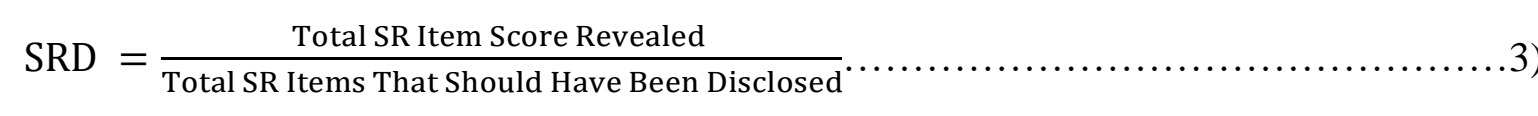




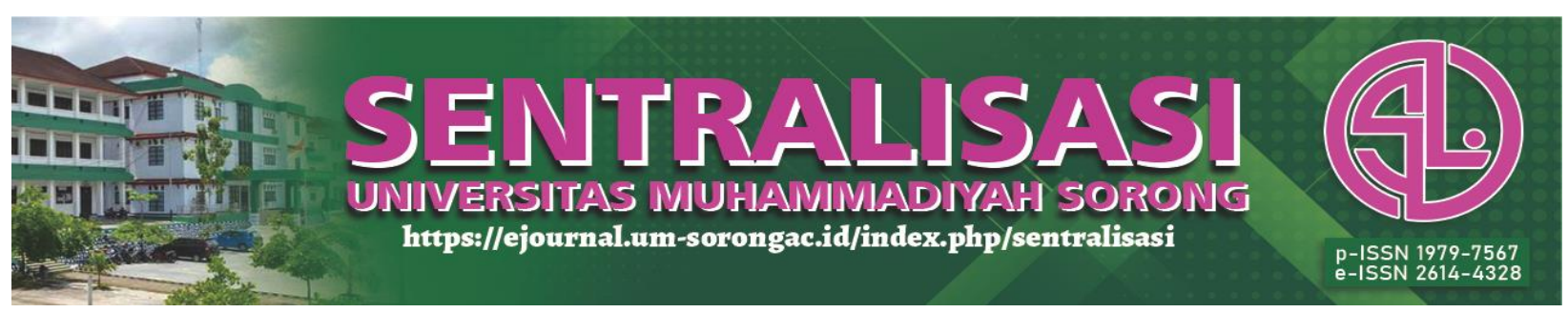

\section{Good Corporate Governance}

The moderating variable is Good Corporate Governance (GCG). In GCG, the Good Corporate Governance Index (GCGI) proxy is used. The formula used is as follows:

$$
\text { GCGI }=\frac{\text { Total items disclosed by the company }}{\text { Expected items }}
$$

\section{Results and Discussion}

\section{Results}

Table1. Descriptive statistics

\begin{tabular}{llrrrr}
\hline & N & Minimum & Maximum & \multicolumn{1}{c}{ Mean } & Std. Deviasi \\
\hline FCF & 57 & $-128,68$ & 269,72 & 71,1643 & 90,18643 \\
ERMD & 57 & 0,29 & 0,91 & 0,6281 & 0,14790 \\
SR & 57 & 0,1209 & 0,9671 & 0,421875 & 0,1616193 \\
PBV & 57 & $-1,85$ & 8,05 & 3,1301 & 2,18189 \\
GCG & 57 & 0,4043 & 0,7873 & 0,575267 & 0,923831 \\
$($ FCF*GCG) & 57 & $-73,49$ & 155,04 & 41,0258 & 51,74356 \\
$($ ERMD*GCG) & 57 & 0,1655 & 0,6051 & 0,361384 & 0,1100460 \\
$\left(\right.$ SR $^{*}$ GCG) & 57 & 0,0875 & 0,5145 & 0,239469 & 0,0956658 \\
Valid N (Listwise) & 57 & & & & \\
& & & & & \\
\hline
\end{tabular}

Source: Processed secondary data

Based on table 1. The descriptive statistical test shows the results that include: Variable (FCF) it is known that the minimum value is -128.68 , with a maximum value of 269.72 and an average value of 71.1643 then the standard deviation of 90.18643. (ERMD) it is known that the minimum value is 0.29 , with a maximum value of 0.91 and an average value of 0.6281 then the standard deviation of 0.14790 . The variable (SR) is known that the minimum value is 0.1209 , with a maximum value of 0.9671 and the average value is 0.421875 then the standard deviation is 0.1616193 . The variable (GCG) is known that the minimum value is 0.4043 , with a maximum value of 0.7873 and an average value of 0.575267 . Standard deviation of 0.923831 . The variable $(\mathrm{FCF} * \mathrm{GCG})$ is known that the minimum value is -73.49 , with the maximum value of 155.04 and the average value of 41.0258 then the standard deviation of 51.74356. Variable (ERMD*GCG) it is known that the value of mi the minimum is 0.1655 , with a maximum value of 0.6051 and an average value of 0.361384 then the standard deviation of 0.1100460 . The variable (SR*GCG) is known that the minimum value is 0.0875 , with a maximum value of 0.5145 and the average value of 0.239469 then the standard deviation of 0.0956658 .

\section{Tabel 2. Regression test results}

\begin{tabular}{lccccc}
\hline \multicolumn{7}{c}{ Unstandardized } \\
Coefficients & & & \\
Model & $\mathrm{B}$ & Std. Error & $\mathrm{t}$ & Sig. & Keterangan \\
\hline 1 (Constant) & 0,294 & 6,150 & 0,48 & 0,962 & - \\
FCF & 0,040 & 0,021 & 1,910 & 0,062 & H1 Rejected \\
ERMD & $-5,815$ & 1,828 & $-3,181$ & 0,002 & H2 Be Accepted
\end{tabular}




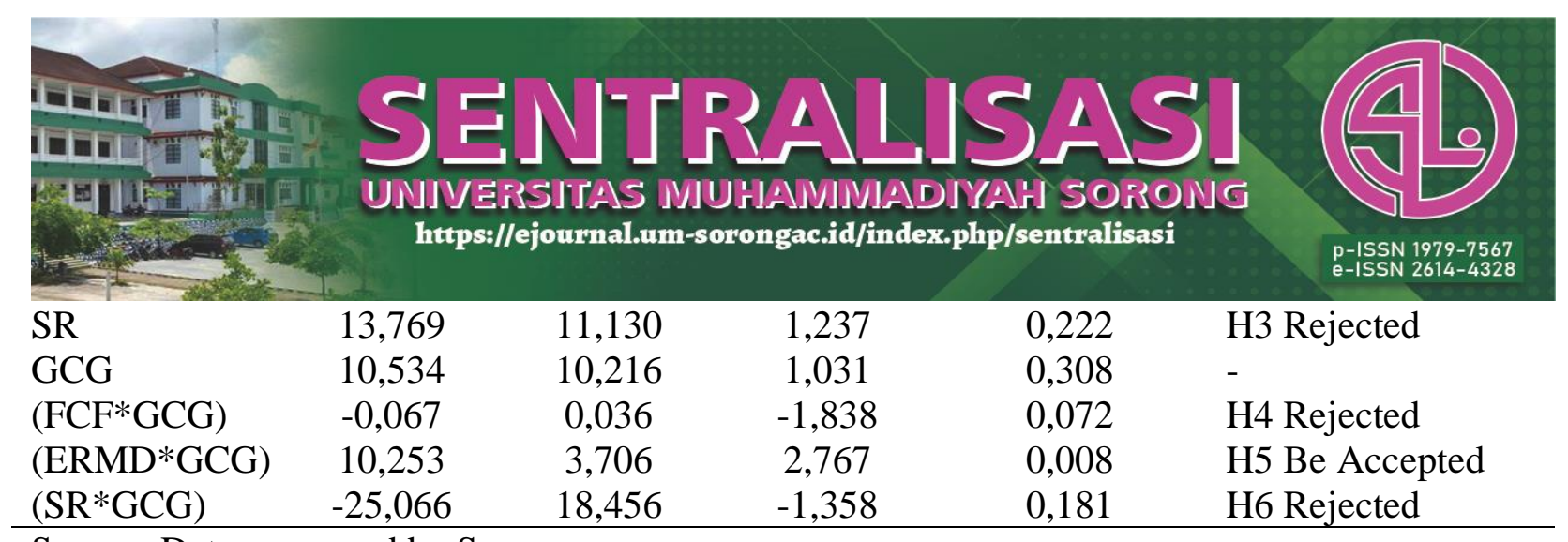

Source: Data processed by Spss

Based on table 2 it is known that the results obtained are:

\section{PBV = 0,294+0,040 FCF-5,815 ERMD+13,769 SR+10,534 GCG-0,067[FCF- GCG]+10,253[ERMD-GCG]-25,066[SR-GCG] + $\varepsilon$}

From the results of the regression equation, it can be explained as follows: The results on the Free Cash Flow coefficient are 0.040 where the coefficient value is positive, which indicates that if the Free Cash Flow increases by 1\%, it will also result in an increase in firm value. by $0.040 \%$. The result of the Enterprise Risk Management Disclosure coefficient is -5.815 where the coefficient value is negative, which indicates that if Enterprise Risk Management Disclosure has decreased by $1 \%$, it will also result in a decrease in firm value of $5.815 \%$.

The results on the Sustainability Report coefficient are 13,769, where the coefficient value is positive, which indicates that if the Sustainability Report increases by $1 \%$, it will also increase the company value by $13.769 \%$.

The results on the Good Corporate Governance coefficient are 10,534, where the coefficient value is positive, which indicates that if Good Corporate Governance increases by $1 \%$, it will also increase the company value by $10.534 \%$. The results on the coefficient (Free Cash Flow*Good Corporate Governance) namely -0.067 , where the coefficient value is negative, which indicates that if Free Cash Flow and Good Corporate Governance decrease by 1\%, it will also result in a decrease in firm value of $0.067 \%$.

The result of the coefficient (Enterprise Risk Management Disclosure*Good Corporate Governance) is 10.253 , where the coefficient value is positive, which indicates that if Enterprise Risk Management Disclosure and Good Corporate Governance increase by $1 \%$, it will also increase the value of the company by $10.253 \%$.

The result of the coefficient (Sustainability Report Good Corporate Governance) is 25.066 where the coefficient value is negative, which indicates that if the Sustainability Report and Good Corporate Governance decreased by $1 \%$, it would also result in a decrease in firm value by $25.066 \%$. obtained from the adjusted $\mathrm{R}$ Square value in the firm value model, which is 0.255 which means $25.5 \%$ where there is a firm value variable at the JII company during the 2015 - 2019 period which can be explained by the FCF, ERMD, SR, GCG variables [FCF-GCG ],[ERMD-GCG],[SR-GCG], while the remaining $74.5 \%$ is explained or influenced by other factors outside the independent variables. 


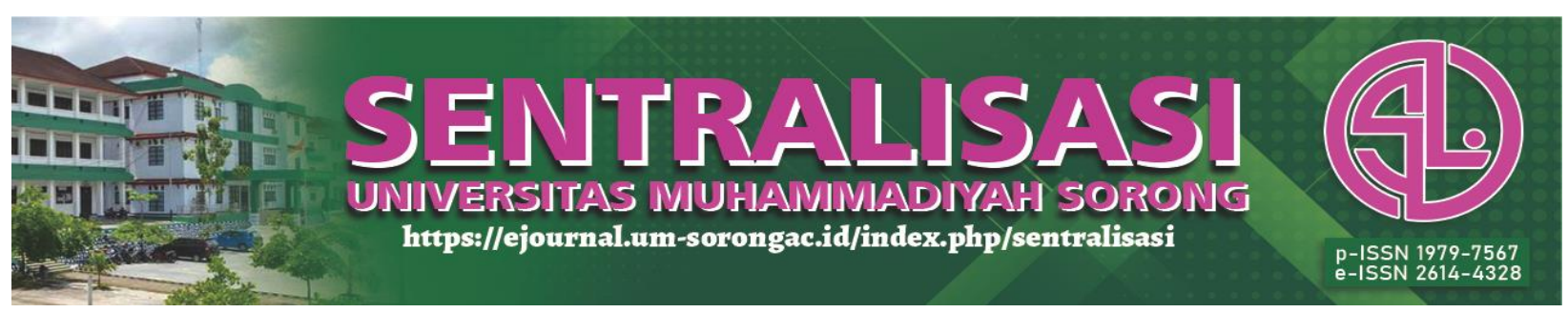

\section{Discussion}

Based on the results that have been carried out in analyzing the influence of FCF on firm value, that the significance value is $0.062(>0.05)$, which means that free cash flow has no effect on firm value. This is due to concerns arising from shareholders that the freecashflow in the company will be used by managers to carry out opportunistic actions which are used to enrich themselves.

The results that have been carried out in analyzing the effect of ERMD on firm value, that the significance value is $0.002(<0.05)$, which means Enterprise Risk Management Disclosure has an effect on firm value. This means that with enterprise risk management disclosure or risk management in a good company, it can increase trust in investors and also to increase and maintain company value.

The results that have been carried out after testing the interaction with the additional GCG variable as a moderating variable, where it is known that the significant value is 0.308 while for the value (FCF * GCG) 0.072 , then GCG is not significant and (FCF * GCG) is not significant. Because usually cash from free cash flow creates a conflict of interest between managers and shareholders. Where managers want more funds and reinvested in projects that can generate profits, in order to increase the incentives they will receive.

Based on the results of calculations that have been carried out after interaction testing with additional GCG variables as moderating variables, it is known that the significant value is 0.308 while the value (ERMD*GCG) is 0.008 , then GCG is not significant and (ERMD*GCG) is significant, so it can be concluded that GCG is a moderating variable between ERMD and firm value. Because the existence of Good Corporate Governance owned by the company can create good governance for the company so that there is no conflict of interest between the company and shareholders, so Good Corporate Governance can moderate the relationship between Enterprise Risk Management and company value because good governance in terms of risk management disclosure is able to make investors interested in assessing the performance of a company. This makes investors consider information in making decisions.

Based on the results of calculations that have been carried out after testing the interaction with the additional GCG variable as a moderating variable, it is known that the value of its significance is 0.308 while for the value (SR * GCG) of 0.181 , then GCG is not significant and (SR * GCG) is not significant, so that it can be concluded that GCG is not a moderating variable between SR and firm value, because the reports from the sustainability report produced by the company by implementing Good Corporate Governance are not considered well by investors. Because investors are more likely to see the results of the company's performance in generating profits and paying dividends. In practice, Corporate Governance is a system which regulates and controls a company that is expected to provide and increase company value to shareholders. 


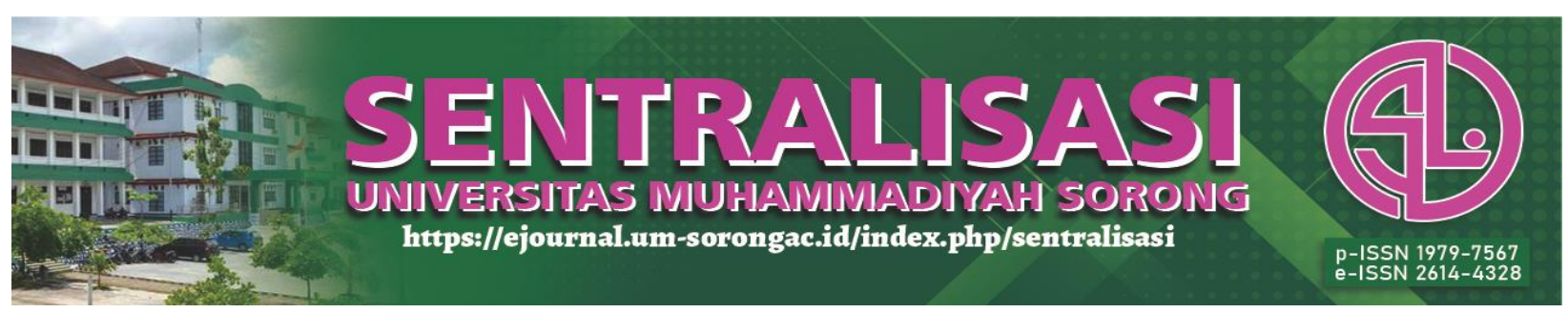

\section{Conclusion}

Based on the results of the research above, it can be concluded that the value of FCF obtained a value of $0.062>0.05$, it can be said that FCF has no effect on firm value. The value of ERMD obtained a value of $0.001<0.05$, it is said that ERMD has an effect on firm value. The value of SR obtained a value of $0.222<0.05$, it can be said that SR has no effect on firm value. The results of the significant $t$ test carried out with interaction testing as an additional moderation, namely the known value of [FCF-GCG] 0.072> 0.05, it can be said that [FCF-GCG] is not significant. The results of the significant $t$ test carried out with interaction testing as an additional moderation, namely the known value of [ERMD-GCG] $0.002<0.05$, it can be said that [ERMD-GCG] is significant. The results of the test the significance of $t$ was carried out with interaction testing as an additional moderation, namely the value of [SR-GCG] was 0.181 , it can be said that [SR-GCG] was not significant.

\section{Reference}

Ardianto, D., \& Rivandi, M. (2018). Pengaruh Enterprise Risk Management Disclosure, Intellectual Capital Disclosure Dan Struktur Pengelolaan Terhadap Nilai Perusahaan. Jurnal Profita, 11(2), 284. https://doi.org/10.22441/profita.2018.v11.02.009

Cahyaningtyas, S. R., Sasanti, E. E., \& Husnaini, W. (2017). Bank Risk Profile, Good Corporate Governance And Company Values in Banking Companies Go Public in Indonesia. Journal of Economics, Business \& Accountancy Ventura, 20(1), 41. https://doi.org/10.14414/jebav.v20i1.759

Darwanto, \& Chariri, A. (2019). Corporate governance and financial performance in Islamic banks: The role of the sharia supervisory board in multiple-layer management. Banks and Bank Systems, 14(4), 183-191. https://doi.org/10.21511/bbs.14(4).2019.17

Devi, S., Budiasih, I. G. N., \& Badera, I. D. N. (2017). Pengaruh Pengungkapan Enterprise Risk Management Dan Pengungkapan Intellectual Capital Terhadap Nilai Perusahaan. Jurnal Akuntansi Dan Keuangan Indonesia, 14(1), 20-45. https://doi.org/10.21002/jaki.2017.02

Fatchan, I. N., \& Trisnawati, R. (2018). PENGARUH GOOD CORPORATE GOVERNANCE PADA HUBUNGAN ANTARA SUSTAINABILITY REPORT DAN NILAI PERUSAHAAN (Studi Empiris Perusahaan Go Public di Indonesia Periode 2014-2015). Riset Akuntansi Dan Keuangan Indonesia, 1(1), 25-34. https://doi.org/10.23917/reaksi.v1i1.1954

Hardina, L., Sasongko, N., \& Setiawati, E. (2019). Pengaruh Islamicity Performance Index Terhadap Profitabilitas Dengan Intellectual Capital Sebagai Variabel Moderating Pada Perbankan Syariah Di Indonesia. Urecol, 275-282.

Kurniawan, T., Sofyani, H., \& Rahmawati, E. (2018). Pengungkapan Sustainability Report dan Nilai Perusahan: Studi Empiris di Indonesia dan Singapura. Kompartemen: Jurnal Ilmiah Akuntansi, 16(1), 1-20. https://doi.org/10.30595/kompartemen.v16i1.2100

Luthfiyanti, N. K., \& Dahlia, L. (2020). The Effect of Enterprise Risk Management on Financial Distress. Journal of Accounting Auditing and Business, 3(2), 30. 


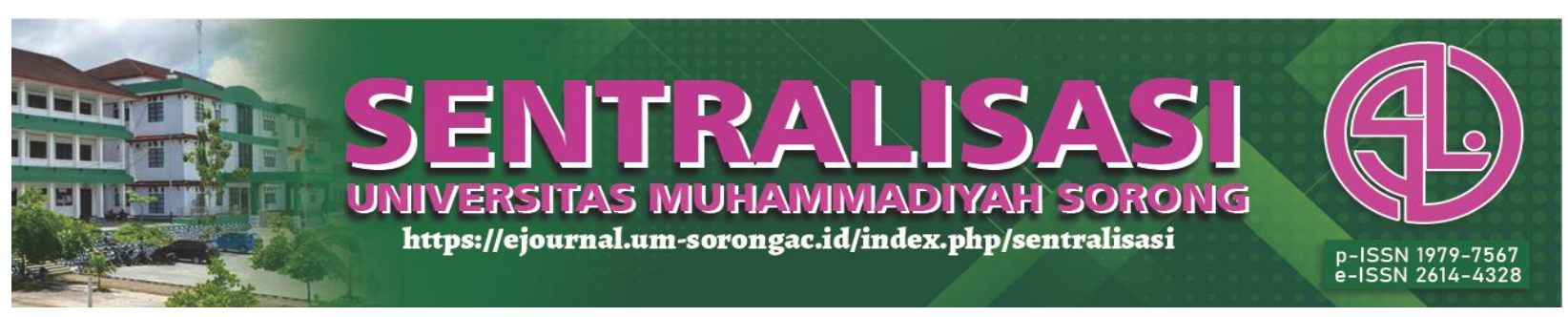

https://doi.org/10.24198/jaab.v3i2.25910

Pradana, R., \& Astika, I. B. P. (2019). Pengaruh Ukuran Perusahaan, Penerapan Good Corporate Governance, dan Pengungkapan Corporate Social Responsibility pada Nilai Perusahaan. EJurnal Akuntansi, 28(3), 1920. https://doi.org/10.24843/eja.2019.v28.i03.p18

Rustiarini, N. W., \& Denpasar, U. M. (2020). Corporate Governance , Konsentrasi Kepemilikan , dan Pengungkapan Enterprise Risk Management. (October).

Suwaldiman, S. (2018). Pengaruh Free Cash Flow, Operating Cash Flow, dan Dividend Payout Ratio Terhadap Nilai Perusahaan. ULTIMA Accounting, 10(1), 52-65. https://doi.org/10.31937/akuntansi.v10i1.845

Trisnawati, R., Sasongko, N., \& Indrawati, L. (2015). Good Corporate Governance , Corporate Social Responsibility Disclosure, and Firm Value. 479-489.

Udayana, E. A. U. (2018). Kemampuan Leverage dalam Memoderasi Pengaruh Good Corporate Governance pada Nilai Perusahaan. E-Jurnal Akuntansi, 2018(1), 110-129. https://doi.org/10.24843/EJA.2018.v23.i01.p05 